$K y \mid E M--176-$ Summ.

\title{
Paducah Site \\ Annual Environmental Report Summary for 1995
}

Project coordinator

V.W. Jones

Technical coordinators

V.W. Jones

S. E. Knaus

Technical Editor

G. Belcher

Published: January 1997

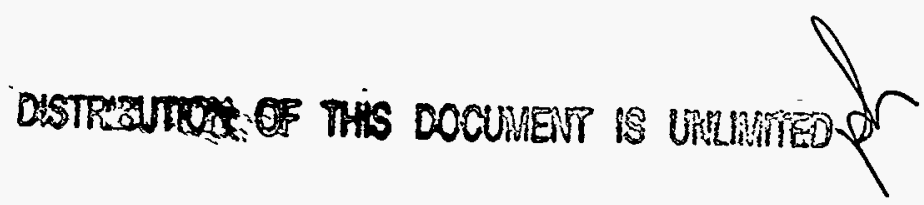

Prepared by the Environmental Management Division, Paducah Site, Lockheed Martin Energy Systems, Inc., 761 Veterans Avenue, Kevil, Kentucky 42053, for the U.S. Department of Energy, under contract No. DE-AC05-84OR21400.

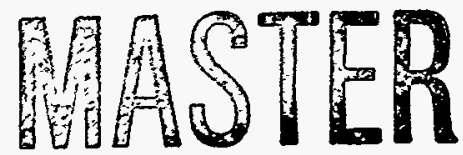




\section{DISCLAIMER}

Portions of this document may be illegible in electronic image products. Images are produced from the best available original document. 


\section{DISCLAIMER}

This report was prepared as an account of work sponsored by an agency of the United States Government. Neither the United States Government nor any agency thereof, nor any of their employees, make any warranty, express or implied, or assumes any legal liability or responsibility for the accuracy, completeness, or usefulness of any information, apparatus, product, or process disclosed, or represents that its use would not infringe privately owned rights. Reference herein to any specific commercial product, process, or service by trade name, trademark, manufacturer, or otherwise does not necessarily constitute or imply its endorsement, recommendation, or favoring by the United States Government or any agency thereof. The views and opinions of authors expressed herein do not necessar. ily state or reflect those of the United States Government or any agency thereof. 


\section{CONTENTS}

Preface

About the Paducah Site

Our Operations are Governed by State and Federal Laws and Regulations and DOE Orders

Restoring the Environment and Managing Waste

Community Participation

We Monitor the Environment

Quality Assurance and Quality Control

We Study the Effects of Radiation and Chemicals

What Do We Mean by Risk?

Radiation

Chemicals

Chemical and Radiological Contaminant Pathways

We Examine the Air

We Monitor Direct Radiation

We Examine Surface Water

We Examine Groundwater

We Sample Sediment

We Monitor Deer

We Monitor Fish and Other Aquatic Life

Comparison of Dose Levels

So ... What Does It All Mean? 


\section{PREFACE}

This pamphlet contains summaries of the environmental programs at the Paducah Site, environmental monitoring and the results, and the impact of DOE operations on the environment and the public for 1995. More detailed information on the material summarized in this pamphlet is available in the Paducah Site Annual Environmental Report for 1995. The data used to compile the site annual environmental report and this summary are published in the Paducah Site Annual Environmental Report for 1995, which is a collection of tables containing effluent monitoring, environmental surveillance, and dose calculation data for 1995.

To obtain copies of any of these documents, contact

Vicki W. Jones

Environmental Compliance Coordinator

Paducah Site

761 Veterans Avenue

Kevil, KY 42053

Telephone: $502-441-5058$ 


\section{ABOUT THE PADUCAH SITE}

The Paducah Gaseous Diffusion Plant (PGDP) is one of two government-owned, contractor-operated uranium enrichment facilities within the U.S. Department of Energy (DOE) complex, see Figure 1. As of July 1, 1993, responsibility for environmental compliance was divided between DOE, as site owner and operator of waste management and environmental remediation projects, and the United States Enrichment Corporation (USEC), a government-owned corporation formed by the National Energy Policy Act of 1992 to take over the nation's uranium enrichment business. Lockheed Martin Energy Systems (Energy Systems), manages and operates the Paducah Site for DOE. Lockheed Martin Utility Services (Utility

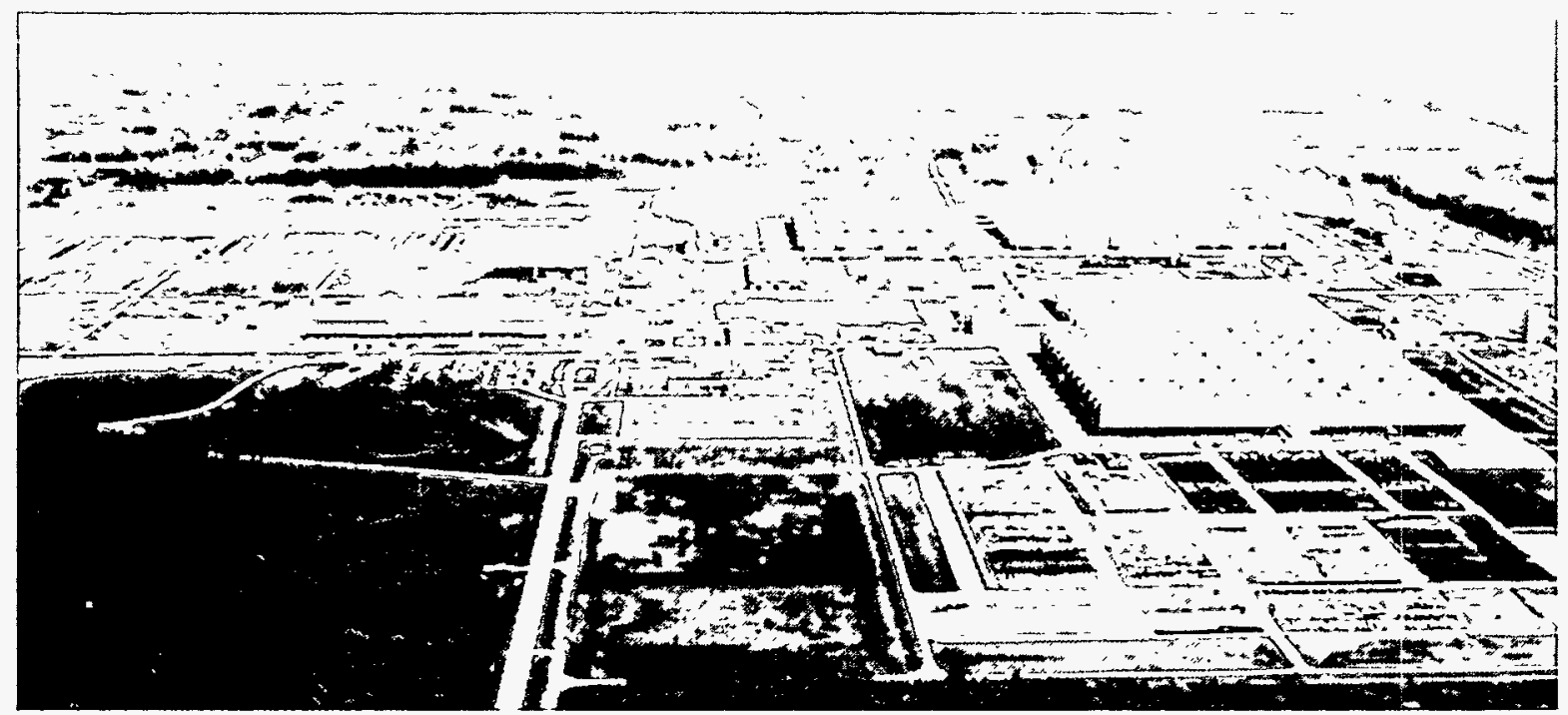

Figure 1. Paducah Gaseous Diffusion Plant is one of two DOE-owned uranium enrichment facilities.

Services) provides operating and maintenance services at PGDP for USEC. DOE is providing oversight of nuclear safety and safeguards and security until the Nuclear Regulatory Commission assumes direct oversight of USEC activities.

The Paducah facility is located in McCracken County, Kentucky, about 10 miles west of the city of Paducah and 3 miles south of the Ohio River. About 750 acres are contained within the security fence, where the buildings containing uranium enrichment process equipment and support facilities are located, see Figure 2. The population within 50 miles of the plant site is about 300,500 .

Before World War II, the area now occupied by the Paducah site was used for agricultural purposes.

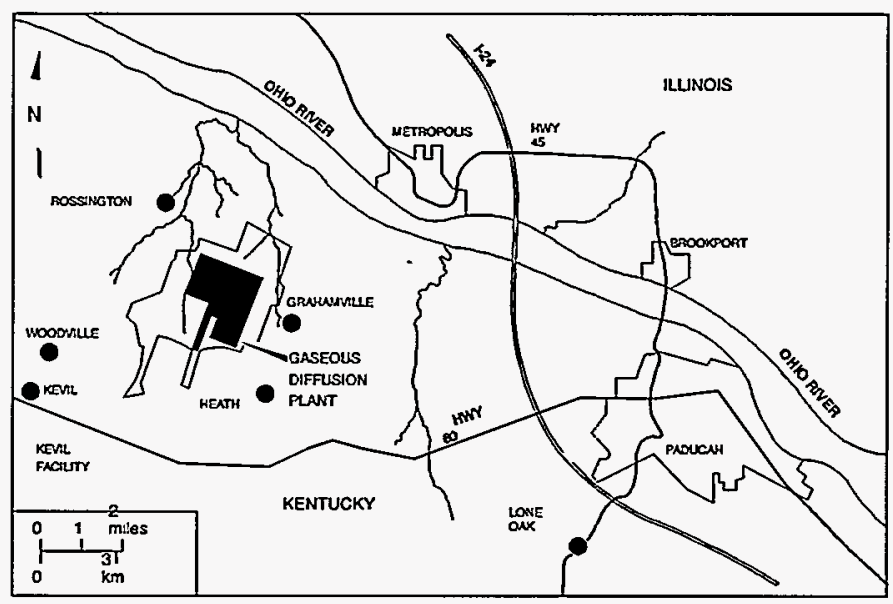

Figure 2. Location of the Paducah site within the state of Kentucky and in relation to the geographic region.

Numerous small farms produced various grain crops and provided pasture for livestock. Early in the war, a 16,126-acre tract was assembled for construction of the Kentucky Ordnance Works, which was 
subsequently operated by the Atlas Powder Company until the end of the war when it was turned over to the Federal Farm Mortgage Corporation and then to the General Services Administration.

In 1950, the Department of Defense and DOE's predecessor, the Atomic Energy Commission (AEC), began efforts to expand fissionable material production capacity. As part of this effort, the National Security Resources Board was instructed to designate power areas within the strategically safe area of the United States. Eight government-owned sites were initially selected as candidate areas, one of which was the Kentucky Ordnance Works site. In October 1950, as a result of joint recommendations from the Department of Defense, Department of State, and the AEC, President Truman directed the AEC to further expand production of atomic weapons. One part of this expansion program was the provision for a new gaseous diffusion plant. In October 1950, the AEC approved the Paducah site for uranium enrichment operations and formally requested the Department of the Army to transfer the site from the General Services Administration to the AEC.

Construction of the Paducah facility was completed in 1954, although production began in 1952 . The facility's mission, uranium enrichment, has continued unchanged, and the original facilities (with substantial upgrading and refurbishment) are still in operation. Of the 7566 acres acquired by the AEC, 1361 were subsequently transferred to the Tennessee Valley Authority (Shawnee Steam Plant site), and 2781 acres were conveyed to the Commonwealth of Kentucky for use in wildlife conservation and recreational purposes, see Figure 3. Thus, the site now occupies 3424 acres.

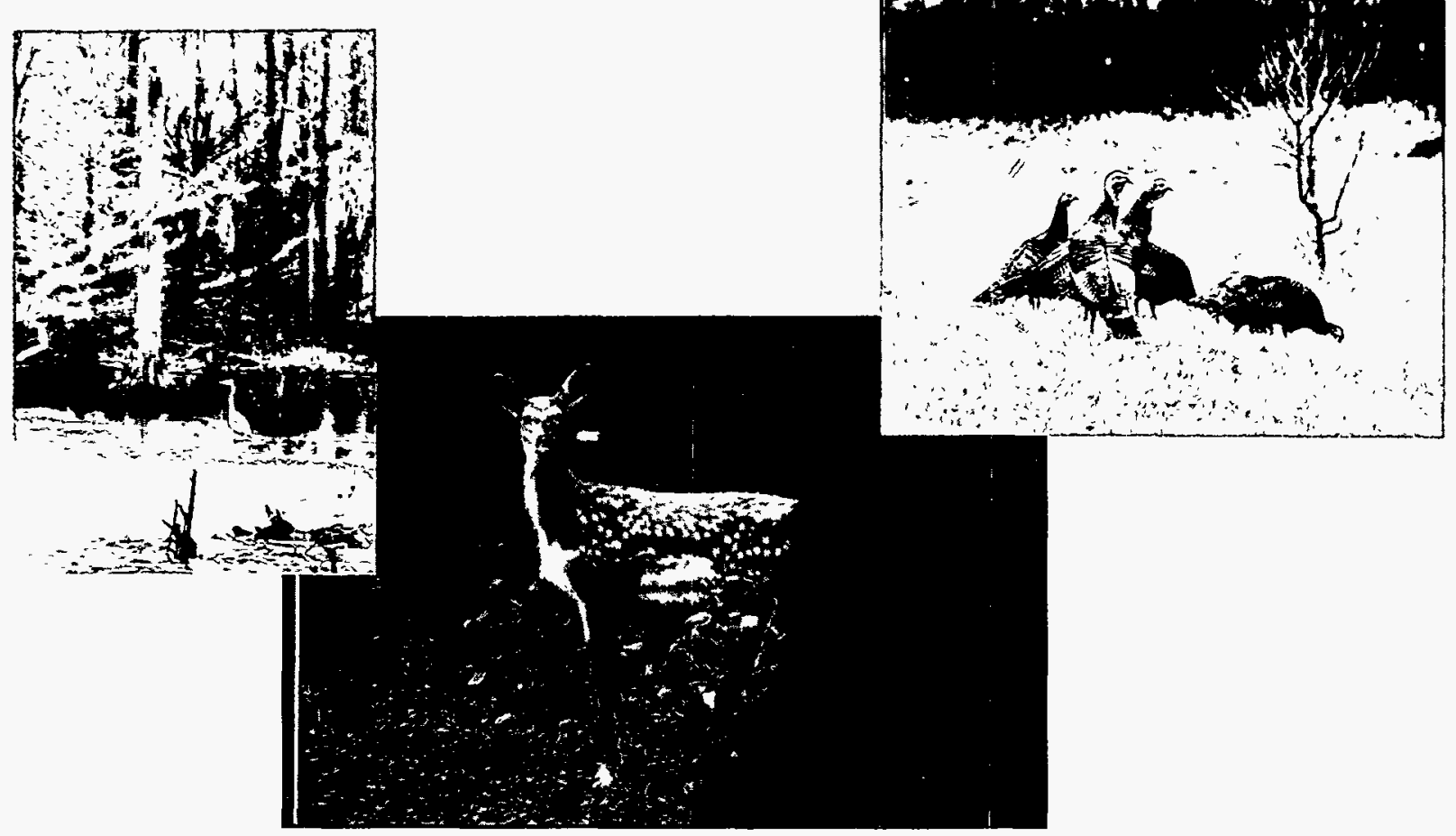

Figure 3. Representative Wildlife that may be found at the Paducah Site and on the West Kentucky Wildlife Management Area. 


\section{OUR OPERATIONS ARE GOVERNED BY STATE AND FEDERAL LAWS AND REGULATIONS AND DOE ORDERS}

To continue operations, the Paducah Site must comply with numerous federal and state laws, such as:

\section{Clean Air Act}

Clean Water Act

Comprehensive Environmental Response, Compensation, and

Liability Act

DOE/Kentucky Agreement in Principle

Emergency Planning and Community Right-To-Know Act

Endangered Species Act

Farmland Protection Act

Federal Facilities Compliance Act

Federal Insecticide, Fungicide, and Rodenticide Act

National Environmental Policy Act

National Historic Preservation Act

Resource Conservation and Recovery Act

Toxic Characteristic Leaching Procedure Federal Facilities Act

Toxic Substances Control Act

DOE Order 5400.1, "General Environmental Protection

Program

DOE Order 5400.5, "Radiation Protection of the Public and the Environment
The philosophy of environmental compliance at the Paducah Site is to protect employee and public health and the environment while complying fully with all applicable environmental rules and regulations. Growth in public awareness and environmental concern in recent years has prompted Congress to pass increasingly stringent laws to protect the environment. In keeping with our philosophy, we continue to work closely with the regulating agencies to minimize the effect of $\mathrm{DOE}$ operations and historic activities on public health and the environment and to ensure continued compliance with regulations.

The U.S. Environmental Protection Agency (EPA) and the Kentucky Department for Environmental Protection are the principal regulatory agencies. These agencies issue permits, review compliance reports, participate in joint monitoring programs, inspect facilities and operations, and oversee compliance with applicable regulations.

\section{RESTORING THE ENVIRONMENT AND MANAGING WASTE}

Environmental restoration and waste management activities are carried out to protect the local population, improve the quality of the environment, and comply with federal and state regulations.
Environmental restoration is the cleanup of wastes in the environment that originated from activities on the site.

Waste management is the control of wastes, including their destruction or permanent storage.

Depleted UF $_{6}$ Program is safe storage of DUF pending final disposition. 


\section{Environmental Restoration}

Environmental restoration is the process of cleaning up inactive waste sites and facilities to ensure that risks to human health and the environment are either eliminated or reduced to safe levels. This task may be accomplished by removing, stabilizing, or treating hazardous substances. The federal law that addresses the restoration of inactive waste sites is the Comprehensive Environmental Response, Compensation, and Liability Act. This legislation includes identification of waste sites with the most urgent need for cleanup because of an increased risk to public health or the environment. These sites are put on the EPA's National Priorities List. On May 31, 1994, the Paducah site was added to this list. Consequently, the site is in the process of finalizing a federal facilities agreement with the appropriate regulatory agencies. This agreement will serve as a comprehensive procedure for remediation of the site and requires the site to submit a plan that outlines remediation priorities and presents schedules for completing the work.

Environmental Restoration activities in 1995 includes the Northwest Treatment Facility and the Lasagna Demonstration Project. The Northwest Treatment Facility is an EPA approved interim action to hydraulically contain off-site mitigation of the northwest plume. This action is a first phase of remedial action for groundwater at the Paducah Site. Four extraction wells and a network of monitoring wells were installed along with a treatment facility, see Figures 4 and 5 . Water extracted from the wells is treated for the trichloroethylene (TCE) by air stripping and by ion exchange to remove the technetium $\left({ }^{99} \mathrm{Tc}\right)$ before being discharged into a Kentucky Pollutant Discharge Elimination System (KPDES) surface water outfall. Between the beginning of operations on August 1995, and January 1996, almost 37,000,000 gallons of water have been treated, resulting in the recovery of approximately 20 gallons of TCE and 0.2 curies of ${ }^{99} \mathrm{Tc}$.

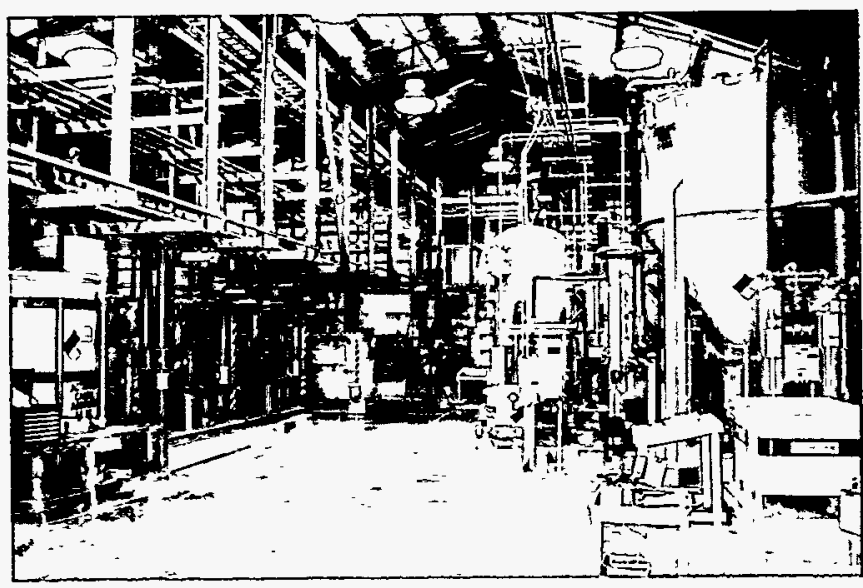

Figure 4. Northwest treatment facility .

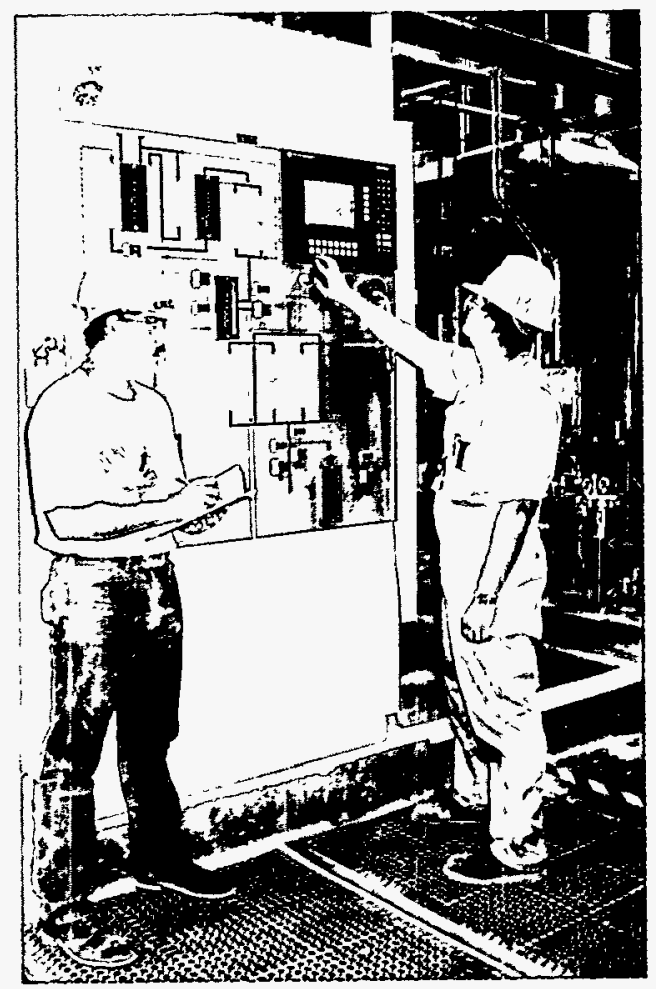

Figure 5. Northwest treatment facility control panel. 
The Lasagna Demonstration Project is being conducted by a research consortium, headed by Monsanto Corporation, to demonstrate the use of electroosmosis in combination with in situ remediation zones to remediate low permeability soils, see Figure 6.

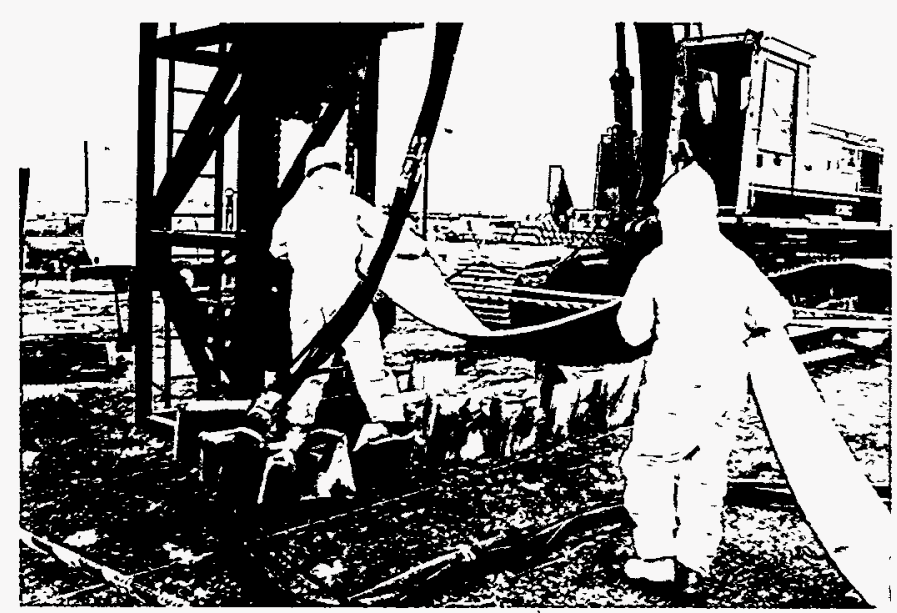

Figure 6. Lasagna ${ }^{\circledR}$ demonstration project installation.

\section{Waste Management}

Gaseous diffusion operations generate hazardous and mixed wastes (waste containing both radioactive and hazardous chemical components). The Paducah site is permitted to treat and temporarily store certain materials on site. These wastes are accumulated on site until they can be shipped off site for permanent treatment, storage, or disposal at authorized sites.

The Paducah Site, as well as all other DOE facilities, prepared a draft site treatment plan that includes the study of options for treatment of mixed wastes that are preferred both environmentally and economically. This plan was submitted to regulators for final approval in March 1995.

Public participation in the early stages of decision making can help identify issues and focus planning efforts. Community awareness and involvement are vital to DOE's success. Federal law requires public comment on proposed cleanup plans, and such public input has a direct bearing on the decisions made. 


\section{Paducah Site}

\section{PCB Capacitor Disposal Project}

On June 30, 1995, DOE granted Energy Systems approval to ship nonradioactive Resource Conservation and Recovery Act (RCRA) and Toxic Substances Control Act (TSCA) waste off-site. By lifting the moratorium and approving the "Procedures for Surface Radiological Characterization of DOE Waste Streams at the Paducah Gaseous Diffusion Plant" Energy Systems Waste Management began preparations to begin shipment of 6240 polychlorinated biphenyl (PCB) capacitors for disposal. Beginning in November 1995, capacitors have been taken out of storage, surveyed, repackaged and certified for off-site release, see Figures 7 and 8 . The post-moratorium shipping campaign began with a shipment of 276 capacitors to the Rollins Environmental Site Services facility in Deer Park, Texas, on December 15, 1995. The PCB capacitor disposal project supports the Uranium Enrichment TSCA Federal Facility Compliance Agreement between DOE and the EPA.

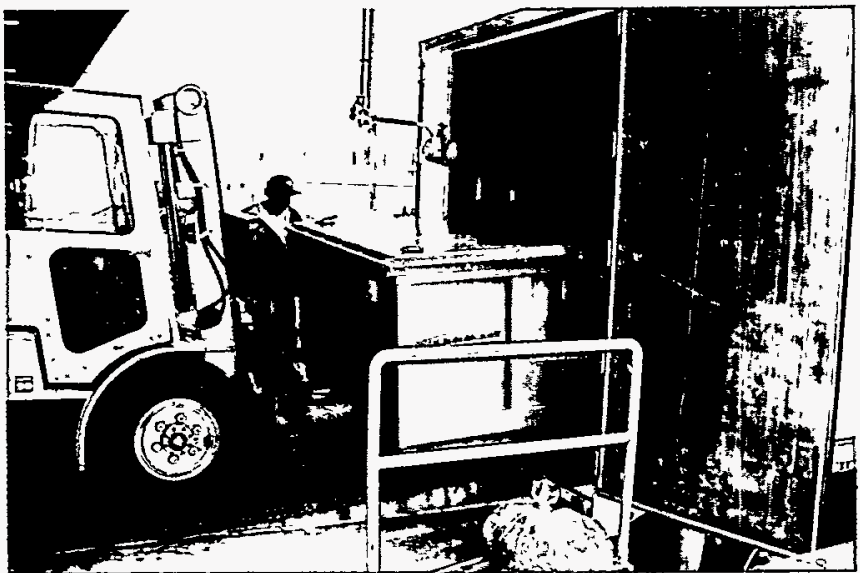

Figure 8. Loading the shipping container.

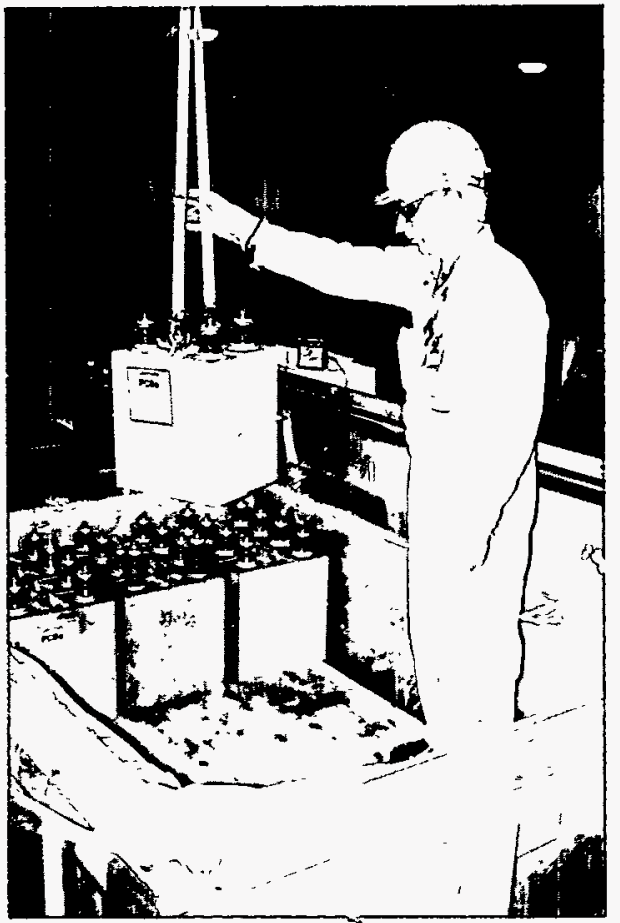

Figure 7. Placing the capacitors into the shipping containers.

The Nickel Ingot Asbestos Removal Project provided for the removal of asbestos from 8,892 nickel ingots. This project brought the nickel ingots and their storage locations into compliance with the National Emission Standards for the Hazardous Air Pollutants regulations. Abatement activities were completed on September 28, 1995. Figure 9 shows a nickel ingot weighing between 2,000 and 3,000 pounds being removed from a conveyer system utilized for ingot movement through the asbestos abatement enclosure.

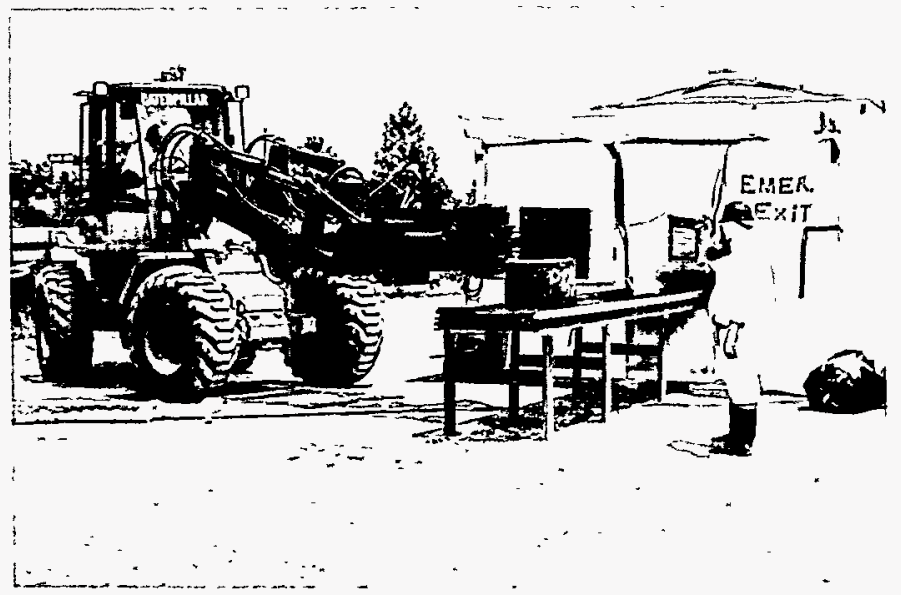

Figure 9. Nickel ingot after asbestos removal. 


\section{Waste Minimization/Pollution Prevention Program}

The Waste Minimization/Pollution Prevention Program provides guidance and objectives for minimizing solid waste generation and discharges to the environment. Conserving natural resources and protecting the environment is DOE policy.

In $1995,16,036$ pounds of white office paper and 535 pounds of aluminum cans were recycled.

\section{Cylinder Management Program}

As part of the Defense Nuclear Facility Safety Board (DNFSB) recommendations, new depleted UF6 Cylinder Yards are being constructed. These new concrete cylinder storage yards will prevent the cylinders from being in contact with the ground as well as provide adequate inspection configuration, see Figure 10.

\section{COMMUNITY PARTICIPATION}

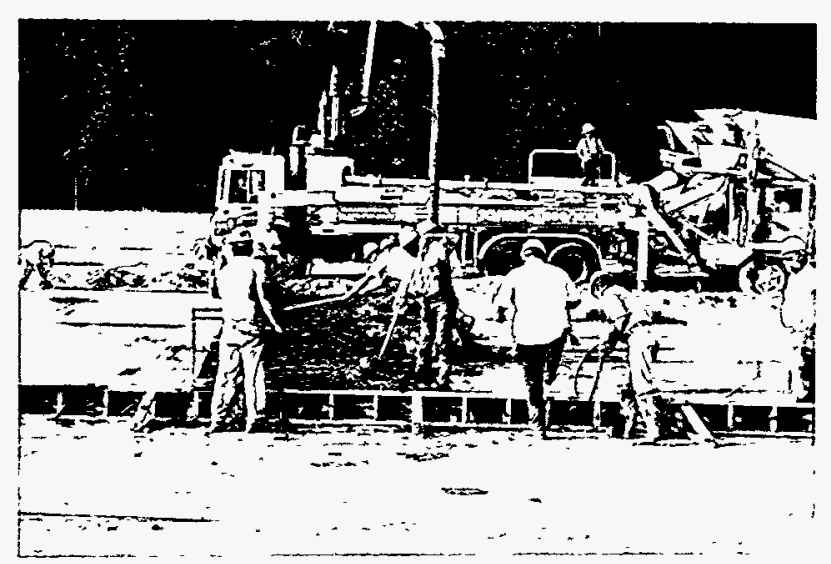

Figure 10. Cylinder storage yard construction.

The Paducah site has a comprehensive community relations and public participation program regarding DOE activities at the site. The purpose of the program is to conduct a proactive public involvement program, with outreach components, to foster a spirit of openness and credibility among local citizens and various segments of the public. The program is also geared to provide the public with opportunities to become involved in the decisions affecting environmental issues at the site.

\section{Public Affairs Programs}

\section{Information Bulletins, Fact Sheets, and Public Briefings}

During 1995, the site published a general information bulletin on environmental issues and cleanup activities for DOE operations. The bulletin was distributed to about 4000 recipients throughout the region. Fact sheets on several topics, including the Vortec pilot waste vitrification project, the "Lasagna" in situ soil remediation pilot project, Site Specific Advisory Boards (SSAB), and the depleted uranium hexafluoride program were also published and distributed.

A total of seven public meetings and two press conferences were held in 1995 . Some of the meetings were general in nature, covering a range of environmental restoration and waste management topics, while others dealt with specific issues, such as the Waste Management programmatic Environmental Impact Statement, future land use, and the feasibility and desirability of forming a SSAB at Paducah. 


\section{Site Specific Advisory Board}

DOE, using an independent facilitator, assessed the need for, then began the process of establishing a Site Specific Advisory Board at Paducah. The board will be comprised of members representing virtually all those interested in DOE Paducah Site activities. Names of potential candidates for membership were sent to DOE Headquarters for final approval to officially charter the board under the Federal Advisory Committees Act.

\section{Earth Day}

Personnel from the Paducah Site and the Kentucky Division of Fish and Wildlife Resources jointly sponsored, planned, and implemented the 1995 Earth Day activities.

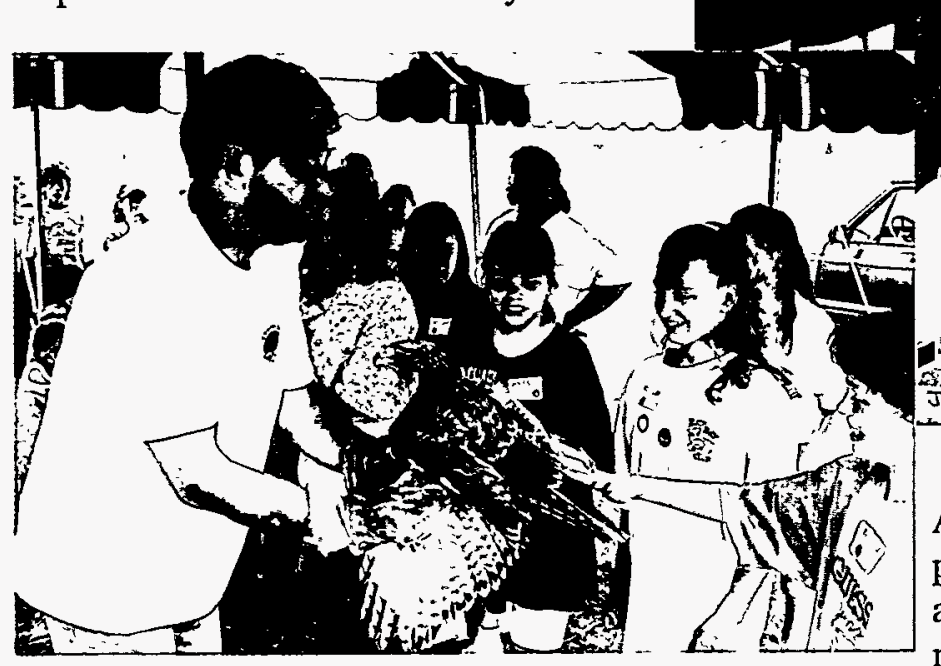

Figure 12. "Birds of Prey" exhibit.

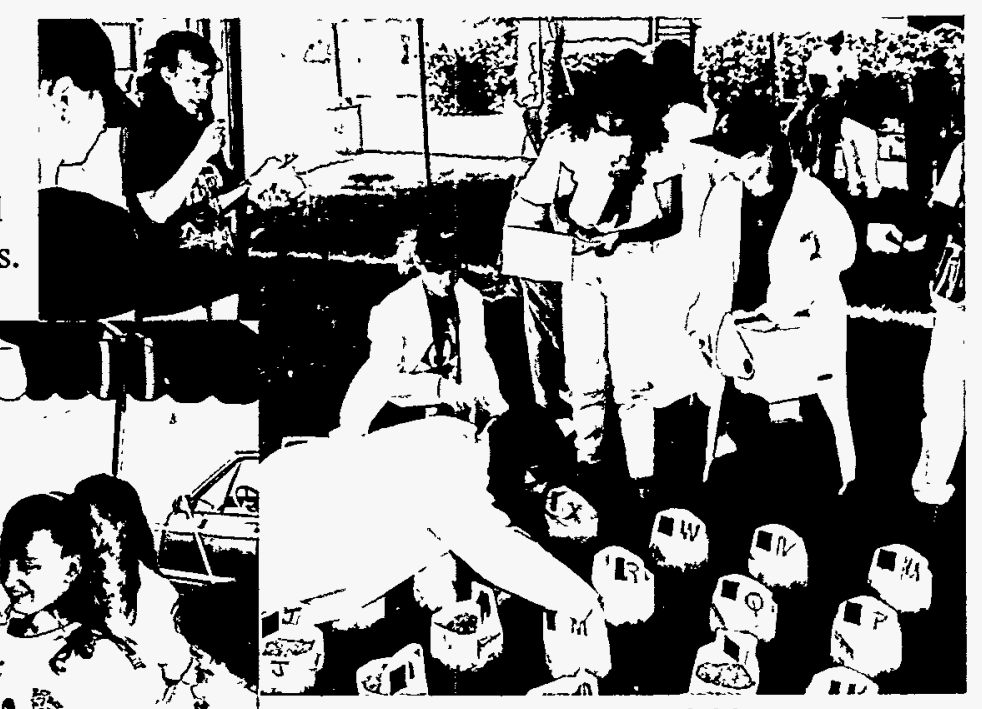

Figure 11. Earth Day Activities.

A wide variety of environmental educational programs were available. Many of the activities were hands-on, in which the students made decisions and took actions based on those decisions, see Figure 11. Other displays provided education about specific aspects of the environment such as "Birds of Prey", see Figure 12. This display was one of the favorites among the nearly 1,000 sixth graders attending the 4-day event.

\section{WE MONITOR THE ENVIRONMENT}

The environmental monitoring program at the Paducah site has two components-effluent monitoring and environmental surveillance, both of which are intended to demonstrate that Paducah Site operations comply with DOE criteria as well as other applicable federal, state, and local standards and requirements.

Information from monitoring and surveillance is also used to document compliance with appropriate standards, identify trends, inform the public, and contribute to general environmental knowledge. We
Effluent monitoring is sampling known air and water discharge points to determine the amount of radioactive and chemical contaminants (if any) contained in the released material.

Environmental surveillance is sampling air, water, soil, and wildlife to detect any radioactive or chemical contaminants that might result from DOE activities. 
monitor the local environment to acquire data so that we may reduce and, where practical, eliminate the release of radioactive and nonradioactive environmental pollutants. Information gathered during specific monitoring programs is published in routine reports to local, state, and federal agencies and to the public. The environmental monitoring program assists in fulfilling DOE's policy of protecting the public, employees, and the environment from harm that could be caused by its activities and in reducing negative effects on the environment to the greatest degree practical.

\section{QUALITY ASSURANCE AND QUALITY CONTROL}

When monitoring releases and measuring radiation in the environment, the reliability of the data is of the utmost importance. To ensure that monitoring and measurement results are accurate, the Paducah Site has a quality assurance and quality control program based on guidelines from the EPA, the American Society for Testing and Materials, and other federal and state agencies. The Utility Services Environmental Monitoring Group at the Paducah Site administers internal quality control programs to ensure reliability of the data on a day-to-day basis.

\section{WE STUDY THE EFFECTS OF RADIATION AND CHEMICALS}

Activities at the Paducah Site involve handling radioactive materials and working with chemicals known to be harmful to humans and the environment. Radiological and chemical "dose" assessments evaluate the possible exposure of the public to radioactive elements and harmful chemicals from DOE operations at the site. We assess and record compliance with regulations for protection of employees, the public, and the environment.

The most important potential source of exposure to radiation from the Paducah Site is direct external radiation from, and ingestion of, sediment in or near the Little Bayou Creek bed. The most important potential source of exposure to harmful chemicals is PCBs in liquid effluents and fish.

Thousands of samples of sediment, biota, surface water, and groundwater are analyzed each year, Figure 13 . The results are used to determine the amount of exposure that a hypothetical, "maximally exposed" individual could receive in a year as a result of DOE operations at the site.

\section{WHAT DO WE MEAN BY RISK?}

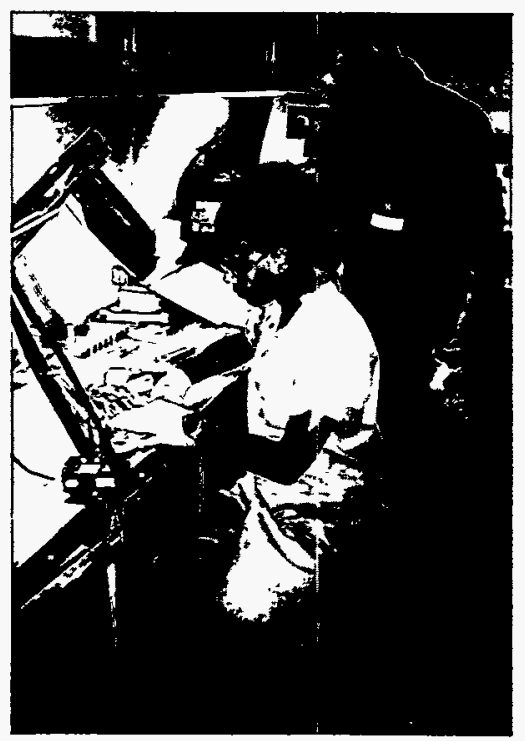

Figure 13. Analysis of samples.

When we estimate the risk associated with activities on the DOE site and the West Kentucky Wildlife Management Area, we are calculating the odds of activities on the site affecting the health of the local population. These calculations are based on known effects that specific chemicals and radiation have on the human body. All of the sampling and analysis compiled in the Paducah Site annual environmental report culminate in the calculation of "dose" of radiation and chemicals to the public (if any) that can be attributed to DOE activities at the site. 
The calculated maximum effective dose equivalent for radiation in 1995 was $1.37 \mathrm{mrem}$. This calculation is based on a hypothetical adult who would have received the maximum exposure from all Paducah Site sources during the year. This amount is about $0.005 \%$ of the dose that an individual receives from natural local background radiation sources, which averages 300 mrem per year. Figure 14 shows how the potential dose of 1.37 mrem per year compares with the DOE limit and the average dose from background radiation to residents in the Paducah area.

Paducah uses the concept of the maximally exposed individual when estimating its contribution to the dose to the off-site population to ensure that the estimate is the highest any one individual could have received as a result of DOE operations. In reality, however, no individual actually receives a dose this high from DOE operations at the site.

\section{RADIAT』ON}

Radioactive material contains unstable atoms (isotopes) that become stable by emitting electromagnetic radiation and high-energy particles. All naturally occurring and human-made isotopes are identical with regard to the particles they emit.

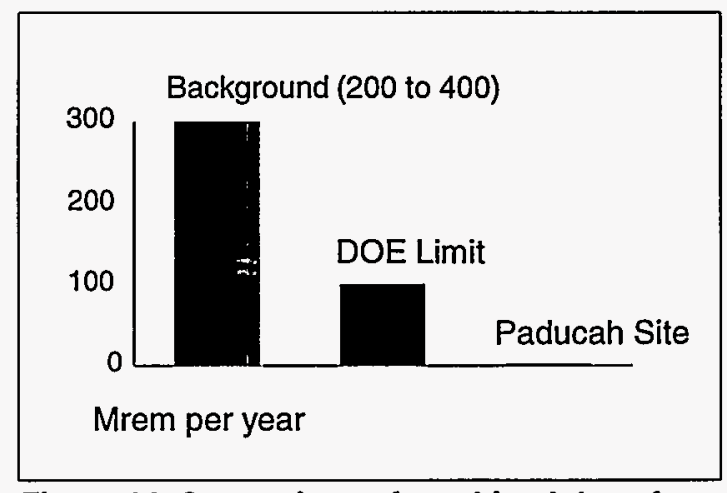

Figure 14. Comparison of combined dose from all exposure pathways from the Paducah site to background dose and the DOE limit.

\section{CHEMICALS}

Chemical dose is the estimate of the amount of a chemical to which a human body is exposed daily.

Toxicity refers to the adverse effects, ranging from mild irritation to death, that a chemical can have on human health. Dose estimates are compared with EPA standards to benchmark their level of toxicity.
Dose is an estimate of the amount of energy absorbed per unit of mass (in units of rads or grays or submultiples thereof).

Dose equivalent is a measure of the amount of effective radiation absorbed (in units of rem or sieverts or submultiples thereof) when modifying factors such as the type of radiation and its distribution are considered. It places all types of radiation on the same biologically equivalent scale.

Effective dose equivalent relates the dose equivalents to the risk to the whole body.

Committed effective dose equivalent is the total internal dose equivalent received over a 50 -year period from intake of radionuclides in 1 year. 


\section{CHEMICAL AND RADIOLOGICAL CONTAMINANT PATHWAYS}

We can receive internal or external exposure to chemicals and radioactive materials by a number of pathways: direct, airborne, waterborne, and the food chain. We receive radiation directly from cosmic radiation and from particles embedded in soil and suspended in air and water. We can breathe air or drink water that has both chemical and radiological airborne contaminants suspended in it. Airborne contaminants that settle on grass in a pasture can be eaten by cows, and the contaminants could show up in the milk we drink. Likewise, contaminants in water can be ingested and retained by fish we eat, see Figure 15.

At the Paducah site, essentially all of the radiation dose to the public is from radioactive forms of two elements: uranium and technetium. Of the two, 1 curie of uranium $(3000 \mathrm{~kg}$ ) will cause committed dose equivalents 174 times greater than 1 curie of technetium $(59 \mathrm{~g})$ if swallowed and $1.42 \times 10^{4}$ times greater if inhaled.

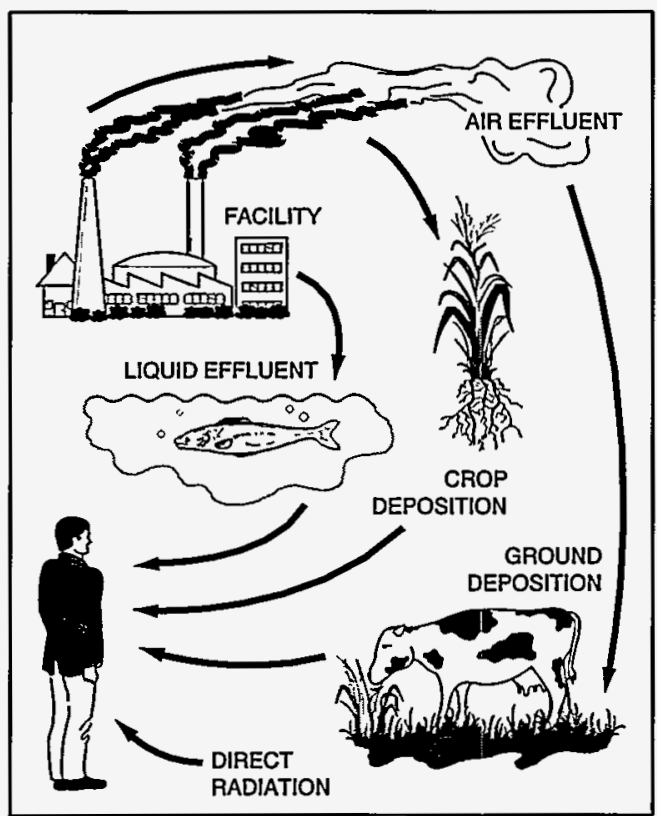

Figure 15. Possible pathways for radiation and chemicals to reach humans.

\section{WE EXAMINE THE AIR}

The air monitoring program provides information to protect the health of site employees and the general public and to demonstrate compliance with state and federal air quality requirements. The program is revised as necessary to comply with revisions in state and federal requirements and DOE Orders.

Both radiological and nonradiological air emissions from DOE facilities are monitored. Airborne emissions from the Northwest Facility were monitored for technetium, which was within acceptable limits set by DOE and federal and state standards. The average concentrations of technetium were small percentages of the allowable limits set by DOE.

Nonradiological emissions of concern include TCE. Emissions in 1995 were all within applicable limits.

\section{WE MONITOR DIRECT RADIATION}

To determine a realistic exposure time to direct radiation from the Little Bayou Creek area, several assumptions were used. During 1995, the West Kentucky Wildlife Management Area allowed hunting and dog trials in this area from January 1 to March 31 and from September 1 to December 31 (213 days). For exposure in the creeks, an individual was assumed to hunt every other day during this period and spend 30 minutes in the Little Bayou Creek bed. This exposure time is most likely exaggerated as most areas are fenced and signs are posted in this area stating that prolonged exposure could result in a dose above background. Also, observations indicate that hunters spend very little time in creeks near the plant. Using the maximum exposure rate measured in KPDES outfall 011 (which is fenced and posted before 
discharging into Little Bayou Creek) as the worst-case estimate for Little Bayou Creek, the dose above background to this maximally exposed individual would be $1 \mathrm{mrem} /$ year. Even using these extreme assumptions, the potential dose is within the guideline value of less than $10 \mathrm{mrem} / \mathrm{year}$ from any one pathway.

\section{WE EXAMINE SURFACE WATER}

KPDES provides limits for effluents discharged into the surface water. DOE has two outfalls which are routinely sampled. All analytical results were within the limits identified in the KPDES permit. Averaged annual concentration of uranium discharged through the two outfalls for 1995 was $2.9 \mathrm{pCi} / \mathrm{L}$ (DOE's Derived Concentration Guide (DCG) is $600 \mathrm{pCi} / \mathrm{L}$ ). The averaged annual concentration of ${ }^{99} \mathrm{Tc}$ discharged through the two outfalls for 1995 was $15.5 \mathrm{pCi} / \mathrm{L}$ (DCG is $100,000 \mathrm{pCi} / \mathrm{L})$.

Additional surface water monitoring not required by the KPDES permit is performed routinely at the Paducah Site as part of the environmental surveillance program. The net impact of DOE activities on surface waters is evaluated by comparing data from samples collected at a reference location on Massac Creek with information from samples collected upstream and downstream of the plant from Little and Big Bayou Creeks. Sample results

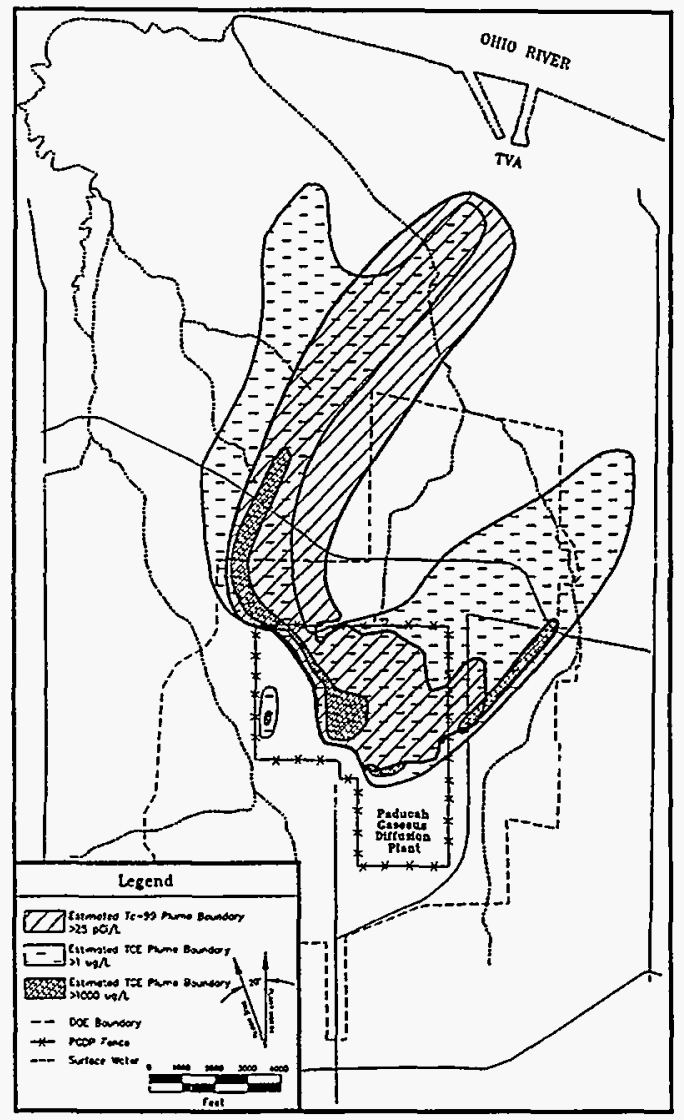

Figure 16 Groundwater contamination near the Paducah Site.

\section{WE EXAMINE GROUNDWATER}

By sampling the groundwater, we are able to evaluate the impact of DOE activities on local groundwater and to limit any activities that have an adverse effect on the groundwater. Federal regulations specify actions to be followed in the groundwater monitoring program. Sampling is conducted at over 200 wells, including site monitoring wells, residential wells, and wells that belong to the Tennessee Valley Authority.

Radiological groundwater monitoring is conducted to identify specific radionuclides as well as general levels of radioactivity. Technetium- $99\left({ }^{99} \mathrm{Tc}\right)$ is the only major threat to the regional gravel aquifer, a local groundwater area that is no longer utilized to provide drinking water to any area residents. Areas contaminated with ${ }^{99} \mathrm{Tc}$ are shown in Figure 16.

Nonradiological groundwater monitoring focuses primarily on TCE, a degreasing agent used by many industries until its harmful environmental effects were discovered. TCE is a dense nonaqueous phase liquid (DNAPL), that is, a liquid with a density greater than water. DNAPLs are extremely difficult to 
remove. In fact, because technology does not yet exist to remove them from aquifers, DNAPLs are a continuing source of groundwater contamination. Although other chemicals are monitored, TCE appears to be the only nonradiological contaminant threatening the regional gravel aquifer at the Paducah Site. TCE-contaminated areas are identified on Figure 16.

In July 1988, upon discovery of contaminated residential wells, the Paducah Site began providing bottled water to residents with affected wells. Since then, DOE has established a water policy that includes extending a municipal water line to the entire area that could be affected by groundwater contamination originating from the Paducah Site. All residents within the area, regardless of whether or not their wells were contaminated, were given the opportunity to receive municipal water at DOE expense when signing an agreement not to use or dig wells on their property.

\section{WE SAMPLE SEDIMENT}

The stream bottom is an important constituent of the aquatic environment. If a pollutant is a suspended solid or is attached to suspended sediment, it can settle to the bottom (thus creating the need for sediment sampling), be filtered by certain organisms, or become attached to plant surfaces. Uranium and PCB levels were higher in downstream Little Bayou Creek than at upstream Little Bayou Creek. In addition, uranium levels downstream Big Bayou Creek were three times higher than upstream Big Bayou Creek; however, 1995 levels were slightly lower than 1994 levels. These elevated levels downstream can be attributed to plant operations (such as runoff for contaminated scrap yards) since the assay is lower than natural uranium. The monitoring program confirms past studies in which uranium and PCBs had been detected. These past studies resulted in the posting of Little Bayou Creek to make the public aware of: (1) PCB contamination and, (2) prolonged exposure could result in a dose above background.

\section{WE MONITOR DEER}

The data from radiological sampling indicated no significant difference between the average concentrations of uranium isotopes in liver or muscle for reservation deer and for background deer taken near Fort Campbell, Ky. One person consuming all of both deer found with measurable levels of both radionuclides, would receive no dose.

\section{WE MONITOR FISH AND OTHER AQUATIC LIFE}

DOE sponsors a biological monitoring program that is conducted each year by Oak Ridge National Laboratory. The program consists of three major tasks: (1) effluent and ambient toxicity monitoring, (2) bioaccumulation monitoring, and (3) ecological monitoring of stream communities.

\section{Toxicity Monitoring}

Ceriodaphnia and fathead minnow toxicity tests of effluents are conducted quarterly. For ambient tests conducted in 1995, there was no consistent evidence of chronic toxicity to fathead minnows for any of the ambient sites. Thus, toxicity to minnows observed in effluent from the continuously flowing outfalls was not observed in instream samples following mixing zones. 


\section{Bioaccumulation Monitoring}

The objectives of the bioaccumulation monitoring are to (1) continue PCB tracking studies in fish from Big Bayou Creek and Little Bayou Creek and (2) conduct screening analyses to detect other contaminants that may be of concern to consumers of fish from these streams. Overall mean concentrations of PCBs immediately downstream of DOE outfalls exceeded concentrations from the reference sites. PCB concentrations appear to have decreased over time at all Big and Little Bayou Creek sites, although the extent of the decrease in upper Little Bayou Creek may have been due in part to habitat changes that affected the size and species of fish available.

\section{Ecological Monitoring}

Quantitative sampling of the fish community was conducted at three sites in Big Bayou Creek, one site in Little Bayou Creek, and at one off-site reference station (Massac Creek) during March and September 1995, Figure 17. Qualitative sampling at one site in Little Bayou Creek was conducted during March 1995. Data on the fish communities of Big Bayou Creek and Little Bayou Creek downstream of the plant were compared to data from reference sites located on Big Bayou Creek above the plant and on Massac Creek. These comparisons indicated no consistent spatial or temporal trends in either densities or mean number of sensitive taxa (mayflies, stoneflies, and caddisflies) that provide strong evidence of major impacts to the macroinvertebrate communities.

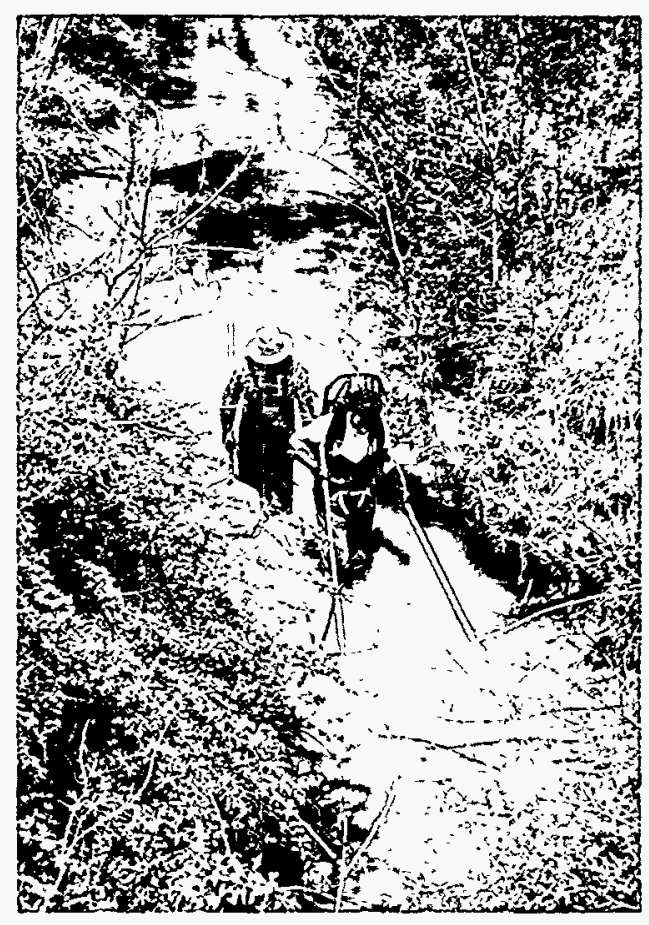




\section{COMPARISON OF DOSE LEVELS}

The dose received by a given individual can vary widely from year to year depending on numerous factors. The average individual in the United States receives a dose from natural exposure that is more than 200 times higher than he or she receives from nuclear industry operations, see Figure 18.

The average dose caused by background radiation varies widely. In the United States, the average is about 300 mrem per year; however, some people in other parts of the world receive a dose more than four times this amount. For example, in some areas of Brazil the dose to inhabitants can be more than 2,000 mrem per year from background radiation. These variations are caused by several factors, most notably the type and amount of naturally occurring radionuclides in the soil. This diversity in background radiation (not human-made radiation) is responsible for the large differences in the dose to average individuals. Because people living in areas with high levels of background radiation do so without proven harm, it is assumed by most in the scientific community that the extremely small variations in dose caused by Paducah Site releases have inconsequential, if any, effect on humans. See Figure 18 for a comparison of dose levels from various sources.

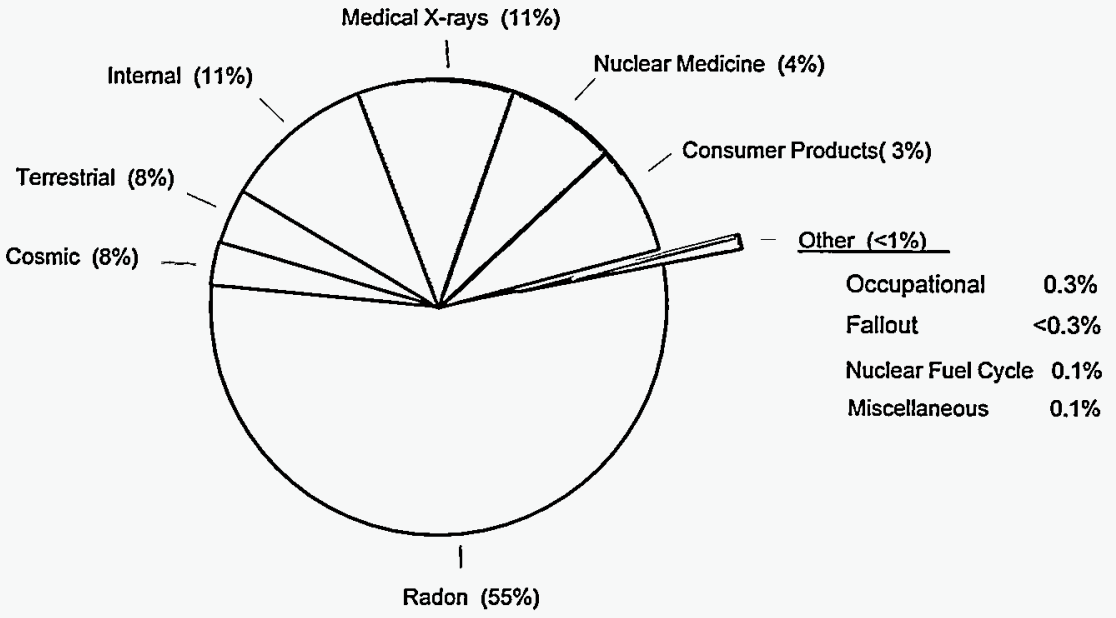

Figure 18. Source of radiation. Radiation has always been present, and every person who has ever lived has been exposed. Although modern technology seems to have greatly increased the exposure rate, this is not necessarily the case. Exposure to human-made radiation varies greatly based on a given individual's product choices and medical treatments. In fact, exposure varies more based on where a person lives than on exposure to human-made sources. For example, the average individual in the United States receives $28 \mathrm{mrem}$ per year from radioactive elements in the soil. However, the average dose from the soil in some areas of France is $\mathbf{3 5 0} \mathrm{mrem}$ per year. (Figure redrawn with permission from the National Council on Radiation Protection and Measurements, lonizing Radiation Exposure of the Population of the United States, NCRP Report No. 93, 1987.) 


\section{SO ... WHAT DOES IT ALL MEAN?}

Everyone who works at the Paducah Site remains committed to working safely, with regard to each other, the public, and the environment. This goal will be accomplished by keeping emissions as low as reasonably achievable, enhancing the strict safety controls that are already in place and by using state-ofthe-art technology to complete environmental remediation projects in the most cost-effective and efficient manner possible. 